\title{
Rapid detection of bovine-specific nucleic acid sequences in cow milk using polymerase chain reaction
}

\author{
Asim A. Osman 1, 2, Ayman M. Mahmoud ${ }^{3, ~, ~ A y m a n ~ S . ~ S o l i m a n ~}{ }^{4}$ \\ ${ }^{1}$ Physiology Department, Faculty of Medicine, Zawia University, Libya \\ ${ }^{2}$ Physiology Department, Faculty of Medicine, GadarifUniversity, Sudan \\ ${ }^{3}$ Physiology Division, Zoology Department, Faculty of Science, Beni-Suef University, Egypt \\ ${ }^{4}$ Physiology Department, Faculty of Medicine, Beni-Suef University, Egypt
}

\section{Email address:}

aymano911@yahoo.com (A. M. Mahmoud), ayman.mahmoud@science.bsu.edu.eg (A. M. Mahmoud)

\section{To cite this article:}

Asim A. Osman, Ayman M. Mahmoud, Ayman S. Soliman. Rapid Detection of Bovine-Specific Nucleic Acid Sequences in Cow Milk Using Polymerase Chain Reaction. International Journal of Nutrition and Food Sciences. Vol. 3, No. 3, 2014, pp. 141-144. doi: $10.11648 /$ j.ijnfs.20140303.12

\begin{abstract}
This study was carried out to evaluatea PCR-based method for detection of DNA in cow milk. It utilized primers targeting the mitochondrial cytochrome-b (mtcyt-b) gene, which was used as a target DNA for PCR amplification. For the specific identification of cow mtcyt-b gene, a pair of primers (CSL1, CSR2), which produced a 386 bp PCR product from milk samples as well as from peripheral blood, were used. Amplification products were visualized on ethidium bromide-stained agarose gels. Amplification products were not detected when the PCR was applied to DNA from different animal species including sheep, camel, deerand human, indicating that the 2 pairs of primers are bovine specific. In conclusion, the PCR-based assay used in this study allowed sensitive and specific identification of cow milk DNA.
\end{abstract}

Keywords: Cytochrome-b, Cow Milk, PCR

\section{Introduction}

Milk is known to be a frequent cause of food allergies and it was reported that most milk proteins, even at low concentration, are potential allergens [1,2]. In addition, cow's milk was reported as the main dairy product responsible for human adverse reaction [3]. Therefore, protection against species substitution or admixture in dairy products is of significant importance [4]. In this regard, different immunological [5], electrophoretic [6] and chromatographic [7] techniques are used for species identification in milk and milk products. Recently, heatstable proteins have been reported to be useful targets for both the detection of animal remains and species identification in foods of animal origin, such as meat [8] and fish products [9].

On the other hand, DNA-based analysis techniques have good applicability in detecting adulteration, and they represent useful complements to methods relying on protein analysis for the identification of animal species as stated by Feligini et al. [10]. Numerous studies addressed that among molecular techniques, polymerase chain reaction (PCR) is the most widely used test for the identification of species of origin in milk [11-16]. In addition, the utility of PCR for the detection of a very small number of DNA molecules has been demonstrated in different studies [17]. Moreover, a study conducted by Feligini et al. [10] revealed that DNAbased techniques have become effective and reliable for commercial dairy products.

In this context, analysis of mitochondrial DNA (mtDNA) has been reported to be a powerful tool for identifying and differentiating animal species in feeds [18]. Therefore, the current prospective study was designed to evaluate a PCRbased method for detection of DNA in cow milk using primers targeting the mitochondrial cytochrome $b$ (mtcyt-b) gene.

\section{Materials and Methods}

\subsection{Study Area}

This study was conducted at the Molecular Biology Laboratory, Faculty of Veterinary Medicine, University of Khartoum and the National Ribat University (Sudan), in collaboration with Beni-Suef University (Egypt) during the 
period from February to July 2012.

\subsection{Study Population}

25 Friesian lactating cows, maintained at the dairy farm of the Department of Animal Production, Sudan University of Science and Technology, were included in the study.

\subsection{Milk Samples Collection}

Before collection, the teats were cleaned with alcohol to avoid samples contamination from skin. Milk $(2.5 \mathrm{ml})$ was collected in sterile $2.5 \mathrm{ml}$ centrifuge tube by hand milking. The collected samples were stored at $4{ }^{\circ} \mathrm{C}$ until testing for extraction of DNA.

\subsection{Blood Samples Collection}

For preparation of positive controls, blood samples were collected in clean sterile vacutainers, containing ethylene diamine tetra acetic acid (EDTA). Blood samples were then centrifuged in bench centrifuge (HettichZentrifugen, D785320 , Germany) in order to separate the buffy coat which is rich in white blood cells and used for DNA extraction.

\subsection{DNA Extraction}

Extraction of DNA from cow's milk and peripheral blood was achieved by using a commercially available QIAamp kit (QIAGEN, Chatsworth, CA) according to the manufacturer's instructions. In details, $200 \mu \mathrm{l}$ of milk samples, $20 \mu \mathrm{l}$ of proteinase $\mathrm{K}$ enzyme stock solution, and $200 \mu \mathrm{l}$ of lysis buffer were pipetted into $1.5 \mathrm{ml}$ eppendorf tube and the mixture was vortexed on the vortexing machine (Janke\& Kunkel, Gmb, Germany) and then incubated at $60^{\circ} \mathrm{C}$ for 10 minutes. $200 \mu \mathrm{l}$ of absolute ethanol were added to the sample and mixed by vortexing. The mixturewas transferred to the QIAamp spin column, and was placed in a clean $2 \mathrm{ml}$ collection tube and centrifuged in microcentrifuge (HettichZentrifugen, Tuttiligen, Germany) at $8000 \mathrm{rpm}$ for 1 minute. The QIAspin column was washed firstly with $500 \mu \mathrm{l}$ of washing buffer 1 at the same previously mentioned centrifugation speed and rewashed using washing buffer 2 at $1200 \mathrm{rpm}$ centrifugation speed for 3 minutes. The QIAamp spin column was then placed in a clean $1.5 \mathrm{ml}$ eppendorf tube and the DNA was eluted with $200 \mu$ l of double distilled water preheated at $70^{\circ} \mathrm{C}$. DNA concentration was determined by spectrophotometer at $260 \mathrm{~nm}$. Five $\mu \mathrm{g}$ of the suspended nucleic acid were used in the PCR amplification.

\subsection{Selection of Cattle Primers for PCR Amplification}

For PCR amplification, a pair of primers was selected from a conserved region of cattle mtcyt-b gene as previously reported by Irwin et al. [19]. The first pair consists of Ruminants Specific Left 1 primer (RSL1) and Cattle Specific Right 2 primer (CSR2) which was used to synthesize the primary bovine-specific PCR product. RSL1 included bases $12-40$ of the positive sense strand 5/CCCAGCCCCCTCAAACATCTCA-3/. CSR2 included bases 357-376 of the complementary strand 5/GGCTATTACTGTGAGCAGA-3/. Using this pair of primers (RSL1 and CSR2) in PCR assay was expected to produce a $386 \mathrm{bp}$ PCR product from bovine mtcyt-b DNA. The primers were synthesized on a DNA synthesizer (Milliigen/Biosearch, MA) and purified using oligo-pak oligonucleotide purification columns (Glen Research Corporation, Sterling, VA) as per manufacturer's instructions.

\subsection{Polymerase Chain Reaction (PCR)}

A stock buffered solution containing $250 \mu 1$ 10X PCR buffer, $100 \mu \mathrm{l}$ of $\mathrm{MgCl}_{2}, 12.5 \mu \mathrm{l}$ of each dATP, dTTP, dGTP and $\mathrm{dCTP}$ was prepared in $1.5 \mathrm{ml}$ eppendorf tube, and double distilled water was added to bring the volume of the stock buffer solution to $1.5 \mathrm{ml}$. the primers were used at a concentration of $20 \mu \mathrm{M}$. Next, $5.0 \mu \mathrm{g}$ of the target DNA were added to $42 \mu \mathrm{l}$ of the stock solution in $0.5 \mathrm{ml}$ PCR tubes and mixed by vortexing. This is followed by $1.0 \mu \mathrm{l}$ of 2.5 U Taq DNA polymerase (Perkin Elmer). All PCR amplification reactions were carried out in a final volume of $50 \mu \mathrm{l}$. The thermal cycling profiles were as follows: 2 min incubation at $95^{\circ} \mathrm{C}$, followed by 40 cycles at $94^{\circ} \mathrm{C}$ for $1 \mathrm{~min}, 57^{\circ} \mathrm{C}$ for $30 \mathrm{sec}$ and $72^{\circ} \mathrm{C}$ for $45 \mathrm{sec}$, and a final incubation at $72^{\circ} \mathrm{C}$ for 10 minutes. Thermal profiles were performed on a Techne PHC-2 thermal cycler (Techne, Princeton, NJ. USA).

\subsection{Visualization of PCR Products}

PCR products were loaded in $1 \%$ agarose gel (Bioproduct, Rockland ME) and electrical power was applied, then the samples were left to migrate for suitable time, using Tris borate EDTA (TBE) buffer. After migration, gels were stained with $0.5 \mu \mathrm{g} / \mathrm{ml}$ ethidium bromide and the cDNA bands were observed in the gel using UV transilluminator. The results were then photographed by gel documentation system.

\section{Results and Discussion}

DNA was successfully extracted from the cow milk samples included in the current study. The PCR-based assay described in this study allowed sensitive and specific identification of cattle mtcyt-b DNA using the primer pair, RSL1 and CSR2.The sensitivity testing revealed that the $386 \mathrm{bp}$ PCR products were not detected from less than $1.0 \mathrm{pg}$ of cow DNA as represented in Figure1. Accordingly, the specificity study for cattle primers demonstrated that mtcyt-b DNA from other species including sheep, camel, deer and human failed to produce the specific 386bp PCR product (Fig.2). Therefore, the current results confirmed that the laboratory specificity of the involved cattle primers is $100 \%$. Using these primers, amplification of the cattle-specific $386 \mathrm{bp}$ PCR product was produced from different milk samples collected from cattle included in this study (Fig. 3-6). 


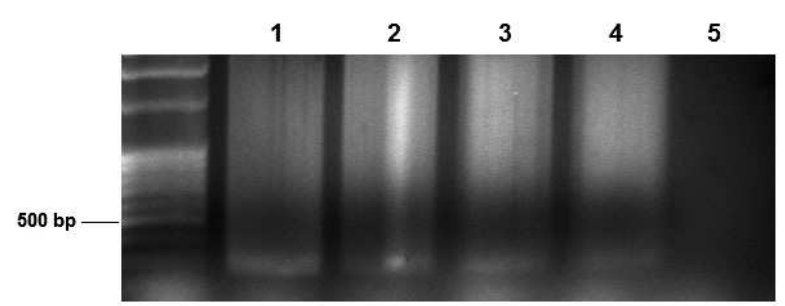

Figure 1. Sensitivity testing using 10 fold serial dilution of the initial DNA concentration. Lanes 1-5: 386 bp PCR products amplified from cow milk DNA at concentrations of $1 \mathrm{ng}, 100 \mathrm{pg}, 10 \mathrm{pg}, 1 \mathrm{pg}$ and $100 \mathrm{fg}$, respectively.

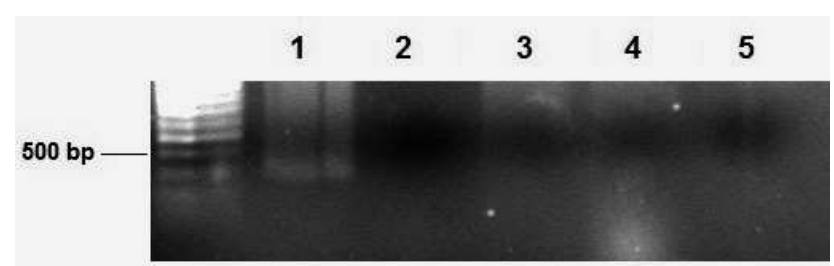

Figure 2. Specificity test. Lane 1: cow milk DNA. Lane 2-5: mtcyt-b DNA of sheep, camel, deer, and human, respectively.

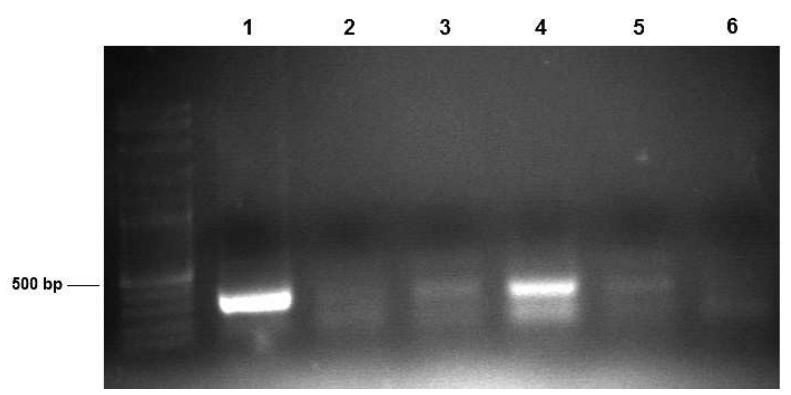

Figure 3. Amplification products of the PCR assay for the detection of cow mtcyt-b. Lane 1: cow DNA (positive control). Lanes 2-5: different cow milk samples. Lane 6: goat DNA (negative control).

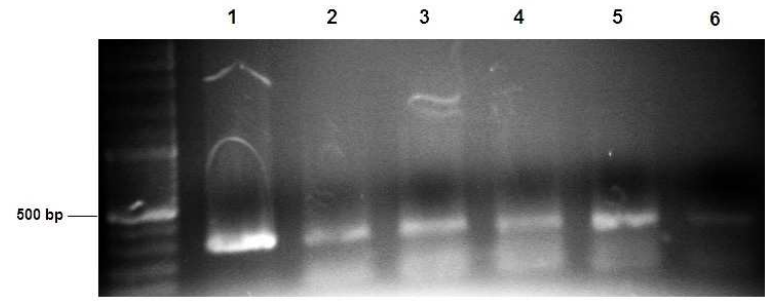

Figure 4. Amplification products of the PCR assay for the detection of cow mtcyt-b. Lane 1: cow DNA (positive control) Lane 2-6: different cow milk samples.

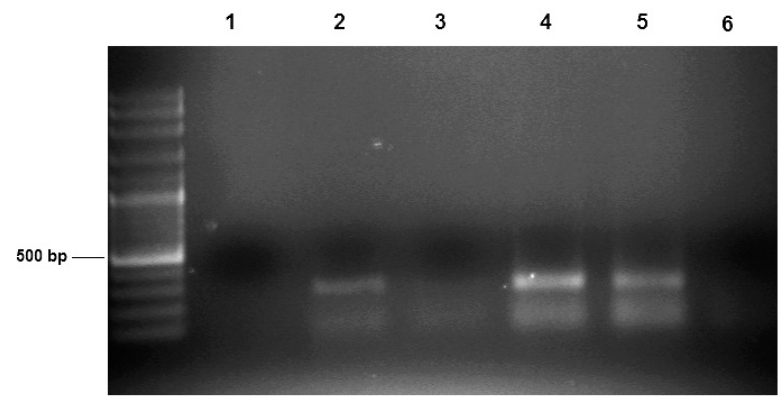

Figure 5. Amplification products of the PCR assay for the detection of cow mtcyt-b. Lanes 2-5: different cow milk samples. Lanes 1 and 6: sheep DNA (negative control).
Recently, species identification of dairy products has received great attention because of its remarkable importance for several reasons related to governmental regulation and public health. It has been reported that mixture in dairy products and species substitution should be observed to be a cause of allergic reactions [4]. In addition, Rance et al [3] reported that cow's milk is the main dairy product responsible for human adverse reaction. Moreover, a study conducted by Sampson [1] demonstrated that most milk proteins, even at low concentration, are potential allergens. Therefore, developing a new screening method for species identification could be of commercial and medical importance.

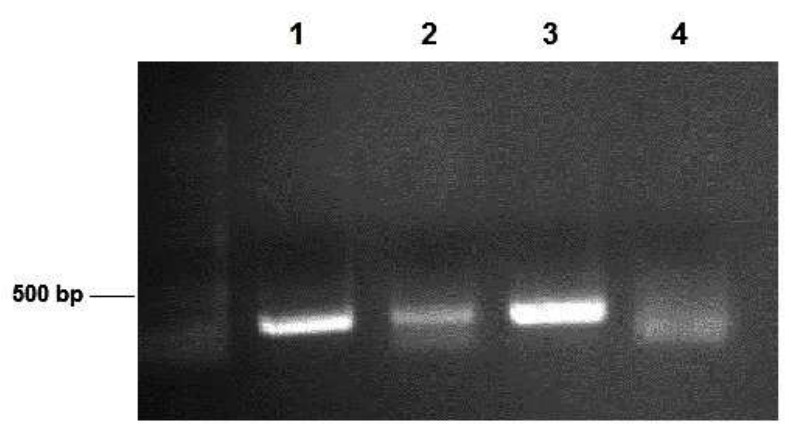

Figure 6. Amplification products of the PCR assay for the detection of cow mtcyt-b. Lane 1: cow DNA (positive control) Lane 2-4: different cow milk samples.

The scientific data presented in this study indicated that DNA extracted from cow milk could serve as substrates for PCR amplification of the full length of the bovinemtcyt-b gene or a fragment of the gene. Since collection of milk is a noninvasive procedure[20], it can often substitute for blood as a source of DNA. The technical convenience of milk as a source of DNA can be expected to increase the field of application of the marker-based methods for genetic analysis of genome as recently reported [20].

On the contrary, Lipkin et al. [21] reported that milk is a less reliable source of DNA than is blood because it requires large size of sample and high concentration of somatic cells. However, the current study used only $200 \mu 1$ of milk samples for extraction of DNA. In addition, the obtained PCR products were of the same length and approximate quantity of the blood DNA products.Further, the PCR assay applied in this study has the advantage of distinguishing milk from closely related species and could be suitable for heat-treated milk. Moreover, the confirmatory diagnosis could be achieved within the same working day, as it requires approximately 3 hours.

In conclusion, the PCR amplification technology, described in this study, provides a simple, rapid, reliable, and sensitive method for species identification and differentiation. The applied assay would be advantageous in the variety of conditions including comparative genomics, species identification in milk and milk products and experimental physiology. 


\section{References}

[1] Sampson, H. A. (2003). Food allergy. J Allergy ClinImmunol, 111, 540-547.

[2] Wal, J. M. (2004). Bovine Milk allergenicity.Ann AllergyAsthmaImmunol, 93, 2-11.

[3] Rance, F., Grandmottet, X., \&Grandjean, H. (2005). Prevalence and main characteristics of schoolchildren diagnosed with food allergies in France. ClinExp Allergy, 35, 167-172.

[4] Bottero, M. T., Civera, T., Nucera, D., Rosati, S., Sacchip, P., Turir, M. (2003). A multiplex polymerase chain reaction for the identification of cows', goats' and sheep's milk in dairy products. J Int Dairy, 13, 77-282.

[5] Addeo, F., Nicolai, M. A., Chianese, L., Moio, L., SpagnaMusso, S., Bocca, A. \& Del Giovine, L. (1995). A control method to detect bovine milk in ewe and water buffalo cheese using immunoblotting.Milchwissenachaft, 50, 83-85.

[6] Cartoni, G. P., Coccioli, F., Jasionowska, R. \&Masci, M. (1998). Determination of cow milk in buffalo milk and Mozzarella cheese by capillary electrophoresis of the whey protein fractions. Italian J Food Sci, 2, 127-131.

[7] Pellegrino, L., De Noni, I., Tirelli, A. \&Resmini, P. (1991).Detection of bovine milk in cheese from minor species by HPLC of whey proteins. Note 1- application to water buffalo Mozzarella cheeses. Sci Tec LattCas, 42, 87101.

[8] Chen F. C. \& Hsieh Y. H. (2000).Detection of pork in heatprocessed meat products by monoclonal antibody-based ELISA. J AOAC Int, 83(1), 79-85.

[9] Piñeiro, C., Barros-Velázquez, J., Vázquez, J., Figueras, A., Gallardo, J. M. (2003). Proteomic as a tool for the investigation of seafood and other marine products. J Proteome Res, 2, 127-135.

[10] Feligini, M., Bonizzi, I., Curik, V.C., Parma, P., Greppi, G.F. and Enne, G. (2005).Detection of adulteration in Italian mozzarella cheese using mitochondrial DNA templates as biomarkers. Food TechnolBiotechnol, 43(1), 91-95.
[11] Rea, S., Chikuni, K., Branciari, R., Sangamayya, R. Ranucci, D. \&Avellini, P. (2001).Use of duplex polymerase chain reaction (duplex-PCR) technique to identify bovine and water buffalo milk used in making mozzarella cheese.J dairy rese, 68, 689-698.

[12] Herman, L. (2001). Determination of the animal of origin of raw food by species-specific PCR Journal of Dairy Rese, 86, 420-436.

[13] Lopez-Calleja, I., Gonzalez Alonso, I., Fajardo, V., Rodriguez, M. A., Hernandez, P. E., Garcia, T. \& Martin, R. (2004). Rapid detection of cow's milk in sheep's and goat's milk by a species-specific PCR technique. J Dairy Sci, 87, 2839-2845.

[14] Maskova, E. \&Paulickova, I. (2006). PCR-based detection of cow's milk in goat and sheep cheese marketed in the Czech Republic. Czech J Food Sci, 24, 127-132.

[15] Abdel-Rahman, S. M.\& Ahmed, M. M. M. (2007). Rapid and sensitive identification of buffalo's, cattle's and sheep's milk using species-specific PCR and PCR-RLFP techniques. Food control, 18, 1246-1249.

[16] Kotowicz, M., Adamczyk, E. \&Bania, J. (2007).Application of a duplex-PCR for detection of cow's milk in goat's milk. Ann Agric Environ Med, 14, 215-218.

[17] Taberlet, P., Griffin, S., Goossens, B., Questiau, S., Manceau, V., Escaravage, N., Waits, L.P. \& Bouvet, J. (1996).Reliable genotyping of samples with very low DNA quantities using PCR. Nucleic Acids Research, 15, 3189-3194.

[18] Cheng, Y. H., Wen, C. M., Ding, S. T., Kao, C. C. \&Kuo, T. Y. (2003). Detecting meat and bone meal in ruminant's feeds by species-specific PCR. J Anim Feed Sci, 12, 851-860.

[19] Irwin, D. M., Kocher, T. D. \& Wilson. A. C. (1991). Evolution of the cytochrome $\mathrm{b}$ gene of mammals. J MolEvol $32,128-144$.

[20] Osman, A. A., Aradaib, I. E. \& Musa, O. A. (2013).Detection of Caprine-specific Nucleic Acid Sequences in Goat Milk Using Polymerase Chain Reaction. Mater Sociomed,25(2), 105-108.

[21] Lipkin, E., ShalOm, A., Khatib, H., Soller, M. \&Friedmann, A.(1993).Milk as a Source of Deoxyribonucleic Acid and as a Substrate for the Polymerase Chain Reaction.J Dairy Sci,76, 2025-2032. 